\title{
ANALISIS PEMERIKSAAN MEAN ARTERIAL PRESSURE (MAP), ROLL OVER TEST (ROT), BODY MASS INDEKS (BMI) SEBAGAI SKRINING PRE- EKLAMPSIA PADA KEHAMILAN
}

\author{
ANALYSIS OF EXAMINING MEAN ARTERIAL \\ PRESSURE (MAP), ROLL OVER TEST (ROT), BODY \\ MASS INDEX (BMI) AS A PRE-ECLAMPSIAN \\ SCREENING IN PREGNANCY
}

\author{
Nining Mustika Ningrum \\ STIKES Insan Cendekia Medika Jombang, Indonesia
}

\begin{abstract}
ABSTRAK
Preeklampsia merupakan suatu ketidaknormalan yang dapat membahayakan ibu dan janin, oleh sebab itu setiap ibu hamil harus dilakukan skrining untuk mendeteksi gejala preeklampsia. Tujuan Penelitian ini adalah menganalisis pengaruh pemeriksaan Mean Arterial Pressure (MAP), Roll Over Test (ROT), Body Mass Indeks (BMI) sebagai skrining preeklampsia pada kehamilan. Jenis penelitian ini adalah analitik kuantitatif dengan menggunakan design penelitian Quasi eksperiment di Praktik Mandiri Bidan wilayah kerja Puskesmas Pulorejo Kabupaten Jombang. Sampel: sebagian ibu hamil Trimester II dan III yang memenuhi kriteria inklusi sebanyak 48 orang, dengan menggunakan tekhnik purposive sampling. Instrumen yang digunakan ialah buku KIA, ceklist. Uji statistik Chisquare dan uji regresi logistik linier. Hasil uji bivariat dengan menggunakan Chi-Square didapatkan ibu hamil dengan MAP positif memiliki resiko lebih besar untuk terjadi preeklampsia, ibu yang memiliki ROT positif memiliki resiko 2 kali terjadi preeklampsia dibanding dengan ROT negatif, ibu yang memiliki berat badan berlebih atau obesitas berdasarkan BMI memiliki resiko lebih besar mengalami preeklampsia. Hasil analisis multivariat yang dilakukan dengan uji regresi logistik secara bersama terdapat pengaruh pemeriksaan MAP, ROT dan BMI sebagai skrining preeklampsia pada kehamilan. Diharapkan kepada bidan adn pemberi pelayanan kepada ibu hamil untuk melakukan pemeriksaan MAP, ROT dan mengontrol kenaikan berat pada ibu hamil berdasarkan Body Mass Indek untuk melakukan skrining adanya preeklampsia pada kehamilan.
\end{abstract}

Kata Kunci: Mean Arteri Pressure, Roll Over Test, Body Mass Indeks, Preekalmpsia

\section{ABSTRACT}

Pre-eclampsia is an abnormality that can harm both the mother and the fetus, therefore every pregnant woman must be screened to detect pre-eclampsia symptoms. The purpose of this study was to analyze the effect of checking Mean Arterial Pressure (MAP), Roll Over Test (ROT), Body Mass Index (BMI) as a screening for pre-eclampsia in pregnancy. This type of research is quantitative analytic using a Quasi-experimental research design in the Midwives Practice Mandiri working area of Puskesmas Pulorejo, Jombang Regency. Sample: 48 pregnant women in Trimester II who met the inclusion criteria were using 
Bali Medika Jurnal.

Vol 7 No 2, 2020: 9-19

ISSN : 2615-7047

DOI: https://doi.org/10.36376/bmj.v7i2

purposive sampling technique. The instruments used were the KIA book, checklist. Chisquare statistical test and logistic regression test. The results of the bivariate test using Chi-Square found that pregnant women with positive MAP had a greater risk of developing pre-eclampsia, mothers who had positive ROT had 2 times the risk of developing preeclampsia compared to negative ROTs, mothers who were overweight or obese based on $B M I$ had a risk more likely to have pre-eclampsia. The results of the multivariate analysis carried out with logistic regression tests together showed the effect of MAP, ROT and BMI examinations as a screening for pre-eclampsia in pregnancy. It is hoped that midwives and service providers for pregnant women to carry out MAP, ROT and control weight gain in pregnant women based on the Body Mass Index to screen for pre-eclampsia in pregnancy.

Keywords: Mean Arterial Pressure, Roll Over Test, Body Mass Index, Pre-eclampsia

\begin{tabular}{ll}
\hline Alamat Korespondensi & : STIKES Insan Cendekia Medika Jombang \\
Email & $:$ niningmustika85@gmail.com
\end{tabular}

\section{PENDAHULUAN}

Kehamilan merupakan suatu hal yang fisiologis dialami oleh seorang wanita, namun pada kehamilan sering terjadi masalah yang berakibat menimbulkan komplikasi dalam kehamilan. Komplikasi yang terjadi pada kehamilan sering muncul ketika usia kehamilan menginjak triester II yaitu pada usia 20 minggu. Salah satu komplikasi yang sering terjadi pada ibu hamil Trimester II adalah Preeklampsia yang ditandai dengan adanya tekanan darah tinggi. Preeklampsia juga sering dikenal dengan istilah toksemia gravidarum atau keracunan pada kehamilan yang ditandai dengan adanya kandungan protein di dalam urine. Saat ini preeklampsia merupakan penyebab utama kematian ibu, baik itu terjadi pada saat kehamilan, persalinan maupun dimasa nifas. Gejala klinik yang sering dialami oleh ibu hamil dengan preeklampsia adalah peningkatan tekanan darah, bengkak pada muka dan ekstremitas, sakit kepala, gangguan visual atau pandangan kabur, nyeri epigastium, adanya protein dalam urine dan apabila tidak segera ditangani akan mengakibatkan kejang / Preeklampsia (Ekasari \& Natalia, 2019).

Data menurut organisasi kesehatan dunia yaitu WHO jumlah kasus preeklampsia pada kehamilan di dunia mencapai angka sebesar 12\% di tahun 2018 . Jumlah kasus preeklampsia di dunia diperkirakan kan semakin meningkat pada tahun 2025 dengan jumlah 1,15 miliar kasus preeklampsia atau sekitar 29\% dari total penduduk di dunia (World Heath Organization, United Nations Children's Fund, United Nations Population Fund, \& The World Bank, 2018). Munurut data yang didapatkan dari Riset Kesehatan Dasar di Indonesia Kasus preeklampsia mencapai $10 \%$ yang sebagian besar terjadi pada primigravida atau ibu yang pertama kali hamil terutama primigravida muda (Cunningham, 2014). Kasus preeklampsia di Jawa Timur yang telah dilaporakan masih tinggi yaitu mencapai angka 18\% dari total komplikasi yang terjadi pada ibu hamil (Dinas Kesehatan Jawa Timur, 2018). Data yang dipeoleh dari Dinas Kesehatan Kabupaten Jombang kasus preeklampsia tercatat sebesar 16\% (Dinas Kesehatan Kabupaten Jombang, 2018).

Sampai saat ini kasus preeklampsi belum diketahui penyebabnya secara pasti, namun para ilmuwan dan pakar sepakat bahwa kasus preeklampsia dapat terjadi diawali dari terdapatnya kelainan yang terjadi pada placenta yang bertugas 
untuk menyuplai darah dari ibu ke janin dan dan juga sebalikanya selama jani masih ada di dalam kandungan. Ibu yang mengalami preeklampsia perkembangan pada pembuluh darah placenta mengalami gangguan yang akibatnya aliran darah dari ibu ke placenta menjadi kurang. Faktor lain yang dapat meningkatkan resiko terjadinya preeklampsia adalah primigravida (kehamilan pertama), riwayat preeklampsia pada kehamilan sebelumnya, malnutrisi, kehamilan kembar, dan mengidap penyakit tertentu seperti hipertensi, diabetes, gangguan pada ginjal, terlalu lama hamil lagi (lebih dari 10 tahun), Obsitas, memiliki keturunan peeeklampsia. Akibat yang bisa terjadi pada kasus preeklampsia yang tidak ditangani secara dini adalah sindrom HELLP yang teridi dari Haemolisis, Elevated liver Enzymes, and Low Platelet count, eklampsia, gangguan pada kardiovaskuler, kegagalan pada paru, ginjal dan hati, koagulopati, solusio placenta serta perdarahan pada otak. Akibat yang bisa terjadi pada janin adalah Intra Uterin Growth Retardation (IUGR) dan Intra Uterin Fetal Death (IUFD) (Keman, 2014). Adanya dampak preeklampsia yang sangat berbahaya terhadap ibu hamil maka perlu dilakukan skrining preeklampsia untuk mendeteksi secara dini adanya preeklampsia sehingga bisa dilakukan penanganan yang tepat agar tidak menimulkan banyak komplikasi pada kehamilan.

Terdapat berbagai metode dalam melakukan deteksi preeklampsia pada ibu hamil yang meliputi Body Mass Index (BMI) merupakan indikator apakah seseorang memiliki berat badan sehat atau tidak sehat, jika BMI seseorang keluar dari status BMI sehat maka risiko kesehatan mereka akan meningkat secara signifikan. Body Mass Index (BMI) dapat dihitung dari tinggi badan dan berat badan seseorang. Peningkatan BMI sangat erat kaitannya dengan terjadinya hipertensi ringan dan atau preeklamsia (NCD Risk Factor Collaboration, 2016). Mean Arterial Pressure (MAP) adalah rata-rata nilai tekanan arterial dinilai dari pengukuran diastole dan sistol, kemudian ditentukan nilai rata-rata atrerin. MAP dikatakan positif jika hasil $>90 \mathrm{mmHg}$, dan negatif jika hasilnya $<90 \mathrm{mmHg}$. Pada wanita hamil resiko rendah, rata-rata tekanan darah arteri pada trimester kedua lebih baik menjadi prediktor preeklampsia disbanding tekanan darah sistolik atau tekanan darah diastolik (Suprihatin, Norontoko, \& Miadi, 2015). Metode Roll Over Test (ROT) adalah pengukuran tekanan darah pada dua posisi yang berbeda, yaitu pada posisi tidur sisi kiri dan posisi tidur terlentang. ROT dikatakan positif jika terjadi perubahan/peningkatan tekanan darah diastolik antara posisi tidur samping dan terlentang $\geq 15 \mathrm{mmHg}$ dan negatif saat perubahan diastol $<15 \mathrm{mmHg}$ (Suprihatin dkk., 2015). Tes ini dikenal dengan nama Roll Over Test yang pertama sekali diperkenalkan oleh Gant dan dilakukan pada usia kehamilan 28 - 32 minggu (Kaytri, 2016).

Gejala paling dini yang sering ditemui pada ibu dengan preeklampsia yaitu terjadinya peningkatan berat badan secara drastis pada pada waktu yang cepat, yang menyebabkan terjadinya odem pada muka dan ekstemitas. Kenaikan berat badan pada ibu hamil harus dikontrol dan disesuaikan dengan Body Mass Indeks (BMI) selama kehamilan pada saat Antenatal Care secara rutin. Selain pada BMI pemeriksaan tekanan darah yang meliputi Mean Arterial Pressure (MAP) dan Roll Over Test (ROT) juga harus dilakukan pada setiap ibu hamil mulai usia kehamilan menginjak trimester II atau 20 minggu (Lalenoh, 2018).

Penelitian yang sudah pernah dilakukan tentang deteksi dan skrining preekalmpsia adalah penelitian yang dilakukan oleh Syahriana, (2018) tentang Indeks Masa Tubuh (IMT), Low Destinity Lipoprotein (LDL) dan High Destinity 
Lipoprotein (HDL) sebagai faktor predictor hipertensi dalam kehamilan menunjukkan bahwa IMT, LDL dan HDL merupakan salah satu predictor terjadinya hipertensi dalam kehamilan. Hasil penelitian yang dilakukan oleh Ghojazedeh (2013) tentang pengukuran Roll Over Test (ROT) pada ibu hamil didapatkan bahwa secara siginifikan nilai ROT positif lebih tinggi pada kelompok yang ibu hamil yang mengalami preeklampsia. Hal tersebut sejalan dengan temuan Walia, M.D.A S and Gupta, (2015) dimana nilai ROT lebih dari $15 \mathrm{mmHg}$ pada ibu hamil normal berisiko 2,191 kali lebih mungkin untuk terjadi preeklampsia. Penelitian lain yang dilakukan Suprihatin (2016) mengkombinasi Antara index masa tubuh (IMT), Mean Arterial Pressure (MAP) untuk memprediksi hipertensi dalam kehamilan menunjukkan bahwa dari $90 \%$ sampel yang masuk kedalam kondisi preeklampsia $85 \%$ diantaranya mampu di diagnosa positif melalui kombinasi ini yaitu apabila ibu hamil memiliki 1 atau lebih tanda positif diantara IMT dan MAP. Namun belum ditemukan hasil pnelitian yang mengkombinasikan tentang Mean Arterial Pressure (MAP), Roll Over Tes (ROT) dan Indeks Masa Tubuh (IMT) sebagai skrining preeklampsia.

Berdasarkan latar belakang diatas peneliti tertarik untuk mengkombinasikan antara pemeriksaan Mean Arterial Pressure (MAP), Roll Over Tes (ROT) dan Indeks Masa Tubuh (IMT) sebagai skrining preeklampsia pada kehamilan di Praktik Mandiri Bidan wilayah Puskesmas Pulorejo Kabupaten Jombang.

\section{METODE PENELITIAN}

Jenis penelitian ini adalah analitik kuantitatif dengan menggunakan design penelitian Quasi Eksperimen yaitu dengan melakukan pemeriksaan Maen Arterial Pressure (MAP, Roll Over Test (ROT) pada saat ibu hamil menginjak usia kehamilan 20 minggu dan selanjutnya mengevaluasi terjadinya preeklampsia pada kehamilan 36-40 minggu dengan melakukan pemeriksaan tekanan darah dan urine albumin. Penelitian ini dilakukan pada bulan Januari s/d Juni 2020 di Praktik Mandiri Bidan Wilayah Puskesmas Pulorejo Kabupaten Jombang.

Populasi dalam penelitian ini adalah Semua ibu hamil Trimester II dan III yang berada di Wilayah Puskesmas Pulorejo Kabupaten Jombang yang berjumlah 65 orang. Sampel pada penelitian ini adalah sebagian ibu hamil Trimester II dan III yang memenuhi kriteria inklusi yang berjumlah 48 orang, dengan menggunakan teknik Purposive sampling. Variabel bebas adalah Pemeriksaan Mean Arterial Pressure (MAP), Roll Over Test (ROT) dan Body Mass Indeks (BMI) sedangkan variabel terikatnya adalah Skrining Preeklampsia pada kehamilan. Instrumen yang digunakan adalah Ceklis, Buku KIA, Tensi meter, Timbangan Berat Badan, dan alat pemeriksaan protein urine.

Metode statistik untuk analisis data ini didapatkan secara Cross Sectional. Adapun uji analisis statistik yang digunakan adalah uji Chi-Square untuk melihat hubungan antar dua variabel yaitu hubungan Mean arterial pressure, roll over test, indeks massa tubuh, dengan hipertensi dalam kehamilan. Setelah dilakukan uji Chisquare, dilakukan uji regresi logistik untuk melihat variabel yang paling signifikant sebagi skrining preeklampsia. 


\section{HASIL}

\section{HASIL DAN PEMBAHASAN}

Tabel 1. Karakteristik responden berdasarkan usia ibu hamil di PMB wilayah Puskesmas Pulorejo Kabupaten Jombang Bulan April 2020.

\begin{tabular}{cllcc}
\hline No & & Usia/tahun & f & Presentase (\%) \\
\hline 1 & $<20$ & & 8 & 16,67 \\
2 & $20-30$ & & 31 & 64,58 \\
3 & $>35$ & & 9 & 18,75 \\
\hline & & Jumlah & 48 & 100
\end{tabular}

Sumber : Data Primer, 2020

Berdasarkan tabel 1 didapatkan bahwa karakteristik responden berdasarkan usia ibu hamil sebagian besar 31 responden (64,58\%) responden berusia 20-35 tahun.

Tabel 2. Karakteristik responden berdasarkan paritas ibu hamil di PMB wilayah kerja Puskesmas Pulorejo Kabupaten Jombang pada bulan April 2020

\begin{tabular}{clcc}
\hline No & \multicolumn{1}{c}{ Paritas } & f & Presentase (\%) \\
\hline 1 & Primigravida & 27 & 56,25 \\
2 & Multigravida & 15 & 31,25 \\
3 & Grande Multigravida & 6 & 12,5 \\
\hline & Jumlah & 48 & 100
\end{tabular}

Sumber : Data Primer 2020

Karakteristik Responden berdasarkan paritas pada tabel 2 menunjukkan bahwa lebih dari setengah yaitu 27 responden $(56,25 \%)$ adalah primigravida.

Tabel 3. Distribusi frekuensi responden berdasarkan Pemeriksaan Mean Arterial Pressure (MAP) pada ibu hamil di PMB wilayah kerja Puskesmas Pulorejo Kabupaten Jombang pada bulan April 2020.

\begin{tabular}{llcc}
\hline No & Mean Arterial Pressure (MAP) & f & Presentase (\%) \\
\hline 1 & MAP positif & 12 & 25 \\
2 & MAP negatif & 34 & 75 \\
\hline \multicolumn{2}{c}{ Jumlah } & 48 & 100 \\
\hline
\end{tabular}

Sumber : Data Primer 2020

Berdasarkan tabel 3 menunjukkan bahwa sebagian besar responden yaitu 34 orang (75\%) memiliki hasil pemeriksaan Mean Arterial Pressure (MAP) negatif.

Tabel 4. Disribusi frekuensi responden berdasarkan hasil pemeriksaan Roll Over Test (ROT) pada ibu hamil di PMB wilayah kerja Puskesmas Pulorejo Kabupaten Jombang pada bulan April 2020

\begin{tabular}{llcc}
\hline No & Roll Over Test (ROT) & f & Presentase (\%) \\
\hline 1 & ROT positif & 7 & 14,6 \\
2 & ROT negatif & 41 & 85,4 \\
\hline
\end{tabular}


Bali Medika Jurnal.

Vol 7 No 2, 2020: 9-19

ISSN : 2615-7047

DOI: https://doi.org/10.36376/bmj.v7i2

$$
\text { Jumlah }
$$

48

100

Sumber : Data Primer 2020

Berdasarkan tabel 4 hampir seluruh responden memiliki hasil pemeriksaan Roll Over Test (ROT) negatif yaitu sebanyak 41 responden $(85,4 \%)$.

Tabel 5. Distribusi responden berdasarkan hasil pemeriksaan Body Mass Indeks (BMI) pada ibu hamil di PMB wilayah kerja puskesmas Puloejo Kabupaten Jombang pada bulan April 2020

\begin{tabular}{clcc}
\hline No & Body Mass Indeks (BMI) & f & Presentase (\%) \\
\hline 1 & Kurus & 5 & 10,4 \\
2 & Normal & 30 & 62,5 \\
3 & Berlebih & 7 & 14,6 \\
4 & Obesitas & 6 & 12,5 \\
\hline \multicolumn{2}{c}{ Jumlah } & 48 & 100 \\
\hline
\end{tabular}

Sumber : Data Primer 2020

Hasil pemeriksaan Body Mass Indeks (BMI) pada tabel 5 menunjukkan bahwa sebagian besar responden memiliki hasil ROT negatif yaitu sebanyak 30 responden $(62,5 \%)$.

Tabel 6. Distribusi frekuensi responden berdasarkan kasus preeklampsia pada ibu hamil di PMB wilayah kerja Puskesmas Pulorejo Kabupaten Jombang pada bulan Juni 2020

\begin{tabular}{cccc}
\hline No & Preeklampsia & f & Presentase (\%) \\
\hline 1 & Preeklampsia & 5 & 10,4 \\
2 & Tidak Preeklampsia & 43 & 89,6 \\
\hline & Jumlah & 48 & 100
\end{tabular}

Sumber : Data Primer 2020

Berdasarkan tabel 6 diatas hampir seluruh responden tidak mengalami preeklampsia yaitu sebanyak 43 responden $(89,6 \%)$

Tabel 7. Tabulasi silang hubungan pemeriksaan Mean Arterial Pressure (MAP) dengan preeklampsia di PMB wilayah kerja Puskesmas Pulorejo Kabupaten Jombang pada bulan Juni 2020

\begin{tabular}{|c|c|c|c|c|c|c|c|}
\hline \multirow{3}{*}{ No } & \multirow{3}{*}{$\begin{array}{c}\text { Mean Arterial Pressure } \\
\text { (MAP) }\end{array}$} & \multicolumn{4}{|c|}{ Kasus Preeklampsia } & \multicolumn{2}{|c|}{ Jumlah } \\
\hline & & \multicolumn{2}{|c|}{$\begin{array}{c}\text { Pre- } \\
\text { eklampsia }\end{array}$} & \multicolumn{2}{|c|}{$\begin{array}{c}\text { Tidak } \\
\text { Preeklampsi } \\
\mathbf{a}\end{array}$} & \multirow[b]{2}{*}{$\mathrm{f}$} & \multirow[b]{2}{*}{$\%$} \\
\hline & & $\mathrm{f}$ & $\%$ & $\mathrm{f}$ & $\%$ & & \\
\hline 1 & MAP positif & 4 & 33,3 & 8 & 66,7 & 12 & 100 \\
\hline 2 & MAP negatif & 1 & 2,9 & 33 & 97,1 & 34 & 100 \\
\hline & Jumlah & 5 & 10,4 & 43 & 89,6 & 48 & 100 \\
\hline
\end{tabular}

Chi-Square : $p$-value : 0,002 r: 0,325

Sumber : Data Primer 2020 
Berdasarkan analisis bivariat dengan meggunakan uji Chi-Square hubungan Mean Arterial Pressure (MAP) dengan Preeklampsia pada ibu hamil di PMB wilayah Puskesmas Pulorejo Kabupaten Jombang didapatkan p-value : 0,002 dimana kurang dari nilai $p \leq 0,05$ dengan nilai koefisien korelasi (r) : 0,325 yang menunjukkan bahwa Ho ditolak yang berarti ada hubungan Mean Arterial Pressure (MAP) dengan preeklampsia pada kehamilan, yang dapat diartikan bahwa semakin besar nilai MAP (positif) maka resiko terjadinya preeklampsia semakin besar, begitupun sebalikan semakin kecil nilai MAP (negatif) maka semakin kecil kemungkinan terjadi preeklampsia.

Tabel 8. Tabulasi silang hubungan pemeriksaan Roll Over Test (ROT) dengan preeklampsia di PMB wilayah kerja Puskesmas Pulorejo Kabupaten Jombang pada bulan Juni 2020

\begin{tabular}{|c|c|c|c|c|c|c|c|}
\hline \multirow{3}{*}{ No } & \multirow{3}{*}{ Roll Over Test (ROT) } & \multicolumn{4}{|c|}{ Kasus Preeklampsia } & \multicolumn{2}{|c|}{ Jumlah } \\
\hline & & \multicolumn{2}{|c|}{$\begin{array}{c}\text { Pre- } \\
\text { eklampsia }\end{array}$} & \multicolumn{2}{|c|}{$\begin{array}{c}\text { Tidak } \\
\text { Preeklampsi } \\
\text { a }\end{array}$} & \multirow[b]{2}{*}{$\mathrm{f}$} & \multirow[b]{2}{*}{$\%$} \\
\hline & & $f$ & $\%$ & $f$ & $\%$ & & \\
\hline 1 & ROT positif & 4 & 57,1 & 3 & 42,9 & 7 & 100 \\
\hline 2 & ROT negatif & 1 & 2,5 & 40 & 97,5 & 41 & 100 \\
\hline \multicolumn{2}{|r|}{ Jumlah } & 5 & 10,4 & 43 & 89,6 & 48 & 100 \\
\hline $\mathrm{Chi}$ & quare : $p$-value $: 0,001 \mathrm{r}: 0$ & & & & & & \\
\hline
\end{tabular}

Sumber : Data Primer 2020

Berdasarkan analisis bivariat dengan meggunakan uji Chi-Square hubungan Roll Over Test (ROT) dengan Preeklampsia pada ibu hamil di PMB wilayah Puskesmas Pulorejo Kabupaten Jombang didapatkan $p$-value : 0,001 dimana kurang dari nilai $p \leq 0,05$ dengan nilai koefisien korelasi (r) : 0,423 yang menunjukkan bahwa Ho ditolak yang berarti ada hubungan Roll Over Test (ROT) dengan preeklampsia pada kehamilan, yang dapat diartikan bahwa semakin besar nilai ROT (positif) maka resiko terjadinya preeklampsia semakin besar, begitupun sebalikan semakin kecil nilai ROT (negatif) maka semakin kecil kemungkinan trjadi preeklampsia.

Tabel 9. Tabulasi silang hubungan pemeriksaan Body Mass Indeks (BMI) dengan preeklampsia di PMB wilayah kerja Puskesmas Pulorejo Kabupaten Jombang pada bulan Juni 2020

\begin{tabular}{|c|c|c|c|c|c|c|c|}
\hline \multirow{3}{*}{ No } & \multirow{3}{*}{ Body Mass Indeks (BMI) } & \multicolumn{4}{|c|}{ Kasus Preeklampsia } & \multicolumn{2}{|c|}{ Jumlah } \\
\hline & & \multicolumn{2}{|c|}{$\begin{array}{c}\text { Pre- } \\
\text { eklampsia }\end{array}$} & \multicolumn{2}{|c|}{$\begin{array}{c}\text { Tidak } \\
\text { Preeklampsi } \\
\text { a }\end{array}$} & \multirow[b]{2}{*}{$\mathrm{f}$} & \multirow[b]{2}{*}{$\%$} \\
\hline & & $\mathrm{f}$ & $\%$ & $\mathrm{f}$ & $\%$ & & \\
\hline 1 & Kurus & 0 & 0 & 5 & 100 & 5 & 100 \\
\hline 2 & Normal & 1 & 3,3 & 29 & 96,7 & 30 & 100 \\
\hline 3 & Berlebih & 1 & 14,3 & 6 & 85,7 & 7 & 100 \\
\hline 4 & Obesitas & 3 & 50 & 3 & 50 & 6 & 100 \\
\hline \multicolumn{2}{|r|}{ Jumlah } & 5 & 10,4 & 43 & 89,6 & 48 & 100 \\
\hline$C$ & dare : $p$-value : $0,002 \quad \mathrm{r}: 0$ & & & & & & \\
\hline
\end{tabular}


Bali Medika Jurnal.

Vol 7 No 2, 2020: 9-19

ISSN : 2615-7047

DOI: https://doi.org/10.36376/bmj.v7i2

Sumber : Data Primer 2020

Berdasarkan analisis bivariat dengan meggunakan uji Chi-Square hubungan Body Mass Indeks (BMI) dengan Preeklampsia pada ibu hamil di PMB wilayah Puskesmas Pulorejo Kabupaten Jombang didapatkan $p$-value : 0,002 dimana kurang dari nilai $p \leq 0,05$ dengan nilai koefisien korelasi (r) : 0,412 yang menunjukkan bahwa Ho ditolak yang berarti ada hubungan Body Mass Indeks (BMI) dengan preeklampsia pada kehamilan, yang dapat diartikan bahwa ibu dengan berat badan berlebih dan obesitas memiliki resiko dua kali lebih besar terjadi preeklampsia dibandingkan dengan ibu hamil yang memiliki berat badan kurus dan normal.

Hasil analisis multivariat regresi logistik pengaruh pemeriksaan Mean Arterial Pressure (MAP), Roll Over Test (ROT) dan Body Mass Indeks (BMI) dengan preeklampsia pada kehamilan menghasilkan nilai $p$-value : 0,000 dimana nilai $p$-value $\leq \alpha$ yang berarti terdapat pengaruh Pemeriksaan Mean Arterial Pressure (MAP), Roll Over Test (ROT) dan Body Mass Indeks (BMI) dengan preeklampsia pada kehamilan.

\section{PEMBAHASAN}

\section{Hubungan Mean Arterial Pressure (MAP) dengan Preeklampsia pada kehamilan}

Berdasarkan hasil penelitian yang dilakukan menunjukkan bahwa 33,3\% ibu hamil dengan MAP positif mengalami preeklampsia dan $97,1 \%$ ibu hamil dengan MAP negatif tidak mengalami preeklampsia. Berdasarkan analisis bivariat dengan meggunakan uji Chi-Square hubungan Mean Arterial Pressure (MAP) dengan Preeklampsia pada ibu hamil di PMB wilayah Puskesmas Pulorejo Kabupaten Jombang didapatkan $p$-value : 0,002 dimana kurang dari nilai $p \leq 0,05$ dengan nilai koefisien korelasi (r) : 0,325 yang menunjukkan bahwa Ho ditolak yang berarti ada hubungan Mean Arterial Pressure (MAP) dengan preeklampsia pada kehamilan, yang dapat diartikan bahwa semakin besar nilai MAP (positif) maka resiko terjadinya preeklampsia semakin besar, begitupun sebalikan semakin kecil nilai MAP (negatif) maka semakin kecil kemungkinan terjadi preeklampsia.

Ibu hamil dengan MAP positif akan memiliki resiko lebih besar terjadi preeklampsia pada usia kehamilan 27 minggu dan 32 minggu. Tekanan arteri rerata ditentukan oleh voleme tekanan darah, tingginya volume tekanan darah seseorang maka nilai arteri rerata juga akan tinggi, begitu juga sebaliknya semakin turun volume tekanan darah maka nilai arteri rerata juga menurun. Pada Trimester II MAP merupakan prediktor preeklampsia yang lebih baik daripada tekanan sistole dan diastole. Berdasarkan hasil penelitian yang dilakukan oleh Kane, S.C.Da Silva Costa, Fand Brennecke, (2014) kepada ibu hamil dengan usia kehamilan 11-19 minggu didapatkan hasil bahwa kombinasi riwayat kesehatan ibu dan MAP positif dapat mengidentifikasi preeklampsia sebesar 62,5\%. Pada Trimester II MAP merupakan prediktor preeklampsia yang lebih baik daripada tekanan sistole dan diastole.

\section{Hubungan Roll Over Test (ROT) dengan Preeklampsia pada kehamilan}

Berdasarkan hasil penelitian yang dilakukan didapatkan hasil bahwa 57,1\% ibu hamil dengan Roll Over Test (ROT) positif mengalami preeklampsia sedangkan $42,9 \%$ tidak mengalami preeklampsia. Pada ibu hamil dengan Roll Over Test (ROT) 
negatif $97,5 \%$ tidak mengalami preeklampsia. Analisis bivariat dengan meggunakan uji Chi-Square hubungan Roll Over Test (ROT) dengan Preeklampsia pada ibu hamil di PMB wilayah Puskesmas Pulorejo Kabupaten Jombang didapatkan $p$-value : 0,001 dimana nilai $p \leq 0,05$ dengan nilai koefisien korelasi (r) : 0,423 menunjukkan bahwa Ho ditolak yang berarti ada hubungan Roll Over Test (ROT) dengan preeklampsia pada kehamilan, yang dapat diartikan bahwa semakin besar nilai ROT (positif) maka resiko terjadinya preeklampsia semakin besar, begitupun sebaliknya semakin kecil nilai ROT (negatif) maka semakin kecil kemungkinan terjadi preeklampsia.

Pada posisi terlentang tekanan dari Vena Cava Inferior (VCI) menyebabkan penurunan aliran balik Vena ke jantung dan mengakibatkan valume tekanan darah dan cardiac output menurun. Berbalik dari lateral ke posisi terlentang dapat mengakibatkan penurunan curah jantung sebesar $25 \%$, sehingga menyebabkan terganggunya aliran darah uteroplacenta sehingga memicu terjadinya preeklampsia pada kehamilan. Hasil penelitian yang dilakukan oleh Kaytri, (2016) yang dilakukan kepada 54 ibu hamil dengan melakukan pemeriksaan ROT di usia kehamilan 28-32 minggu didapatkan hasil bahwa ROT sebagai prediktor preeklampsia memiliki spesifitas $77,7 \%$ dengan tingkat prediktor positif sebesar $64,7 \%$. Ibu hamil dengan ROT positif pada usia kehamilan 28-32 minggu memiliki resiko 2,2 kali lebih besar terkena preeklampsia sehingga ROT memilki hubungan yang signifikan terhadap preeklampsia pada kehamilan.

\section{Hubungan Body Mass Indeks (BMI) dengan Preeklampsia pada kehamilan}

Berdasarkan hasil penelitian yang dilakukan bahwa ibu hamil dengan Berat Badan Berlebih 14,3\% mengalami preeklampsia, sedangkan pada ibu dengan obesitas 50\% mengalami preeklampsia. Kategori Berat badan pada ibu hamil diukur berdasarkan Body Mass Indeks (BMI). Analisis bivariat dengan meggunakan uji Chi-Square hubungan Body Mass Indeks (BMI) dengan Preeklampsia pada ibu hamil di PMB wilayah Puskesmas Pulorejo Kabupaten Jombang didapatkan $p$ value : 0,002 dimana kurang dari nilai $p \leq 0,05$ dengan nilai koefisien korelasi $(\mathrm{r})$ : 0,412 yang menunjukkan bahwa Ho ditolak yang berarti ada hubungan Body Mass Indeks (BMI) dengan preeklampsia, yang dapat diartikan bahwa ibu dengan berat badan berlebih dan obesitas memiliki resiko dua kali lebih besar terjadi preeklampsia dibandingkan dengan ibu hamil yang memiliki berat badan kurus dan normal.

Peningkatan tekanan darah pada dinding arteri disebabkan oleh meningkatnya kebutuhan darah untuk suplai oksigen ke jaringan tubuh dan juga peningkatan volume darah dalam sirkulasi pembuluh darah yang dipicu oleh meningkatnya berat badan pada seseorang. Peningkatan berat badan yang terlalu cepat dalam waktu yang relatif singkat selama kehamilan akan menyebabkan terjadinya retensi cairan yang mengakibatkan adanya odem terutama pada muka dan ekstremitas. Odem inilah ang menjadi gejala dini timbulnya preeklampsia pada kehamilan. Beradsarkan hasil penelitian yang dilakukan oleh Reyes et al (2012) didapatkan bahwa ibu hamil yang memiliki Body Mass Indeks (BMI) >31 menyebabkan dua kali resiko mengalami preeklampsia. Hal ini juga sesuai dengan hsil penelitian yang dilakukan oleh Bilano, et.al (2014) bahwa ibu hamil yang memiliki BMI $>35$ berpeluang lebih besar terkena preeklampsia dari pada ibu 
dengan BMI normal dan menyatakan bahwa BMI memilki pengaruh yang signifikan terhadap preeklampsia pada kehamilan.

Berdasarkan hasil analisis multivariat regresi logistik pengaruh pemeriksaan Mean Arterial Pressure (MAP), Roll Over Test (ROT) dan Body Mass Indeks (BMI) dengan preeklampsia pada kehamilan menghasilkan nilai $p$-value : 0,000 dimana nilai $p$-value $\leq \alpha$ yang berarti terdapat pengaruh Pemeriksaan Mean Arterial Pressure (MAP), Roll Over Test (ROT) dan Body Mass Indeks (BMI) dengan preeklampsia pada kehamilan.

\section{SIMPULAN}

\section{SIMPULAN DAN SARAN}

Berdasarkan penelitian yang telah dilakukan oleh peneliti, didapatkan bahwa ibu hamil dengan Mean Arterial Pressure (MAP) positif memiliki resiko lebih besar terjadinya preeklampsia dibandingkan ibu hamil dengan MAP negatif, ibu hamil degan Roll Over Test (ROT) positif juga memiliki resiko yang besar mengalami preeklampsia sedangkan ibu hamil dengan Body Mass Indeks (BMI) berlebih dan Obesitas juga memiliki resiko terjadi preeklampsi dibandingkan dengan ibu hamil yang memiliki Body Mass Indeks (BMI) yang normal. Dari hal tersebut dapat diambil kesimpulan bahwa Mean Arterial Pressure (MAP), Roll Over Test (ROT) dan Body Mass Indeks (BMI) dapat dijadikan sebagai skrining preeklampsia pada ibu hamil.

\section{SARAN}

Diharapkan kepada semua pemberi layanan kesehatan kepada ibu hamil yaitu bidan dan tenaga kesehatan lain untuk melakukan skrining preeklamsia dengan melakukan pengelolaan kenaikan berat badan ibu hamil berdasarkan Body Mass Indeks (BMI) selama kehamilan, melakukan pemeriksaan Mean Arteri Pressure (MAP), Roll Over Test (ROT) pada setiap Antenatal Care mulai kehamilan Trimester ke II.

\section{DAFTAR PUSTAKA}

Bilano, V., Ota, E., Ganchimeg, T., Mori, R., \& Souza, J. (2014). Risk Factors of Pre-Eclampsia/Eclampsia and Its Adverse Outcomes in Low- and MiddleIncome. PloS one, 9(3), e91198.

Cunningham, F. G. (2014). Obstetri Williams. Jakarta: EGC.

Dinas Kesehatan Jawa Timur. (2018). Profil Dinas Kesehatan Propinsi Jawa Timur. Diambil 1 Desember 2020, dari https://dinkes.jatimprov.go.id/index.php?r=site/file_list\&id_file=10\&id_berit $\mathrm{a}=8$

Dinas Kesehatan Kabupaten Jombang. (2018). Profil Kesehatan Kabupaten Jombang. Diambil 1 Desember 2020, dari https://dinkes.jombangkab.go.id/profil-kesehatan

Ekasari, T., \& Natalia, M. S. (2019). Deteksi Dini Preeklampsia dengan antenatal care. Takalar: Yayasan Ahmar Cendekia Indonesia.

Ghojazadeh, M., Azami-Aghdash, S., Mohammadi, M., Vosoogh, S., Mohammadi, 
Bali Medika Jurnal.

Vol 7 No 2, 2020: 9-19

ISSN : 2615-7047

DOI: https://doi.org/10.36376/bmj.v7i2

S., \& Naghavi-Behzad, M. (2013). Prognostic risk factors for early diagnosing of Preeclampsia in Nulliparas. Nigerian Medical Journal: Journal of the Nigeria Medical Association, 54(5), 344-348.

Kane, S. C., Costa, F. D. S., \& Brennecke, S. P. (2014). New directions in the prediction of pre-eclampsia. Australia and New Zeland Journal of Obstetric and Gynaecology, 52(2).

Kaytri, S. (2016). Role Of Uterine Artery Doppler And Roll Over Test In Prediction Of Pregnancy Induced Hypertension. International Journal of Reproduction, Contraception, Obstetrics and Gynecology, 5(10), 3556-3559.

Keman, K. (2014). Patomekanisme Preeklampsia terkini mengungkapkan teoriteori terbaru. Malang: Universitas Brawijaya Press.

Lalenoh, D. (2018). Preeklampsia Berat dan Eklampsia. Yogyakarta: CV Budi Utama.

NCD Risk Factor Collaboration. (2016). Trends in adult body-mass index in 200 countries from 1975 to 2014: a pooled analysis of 1698 population-based measurement studies with $19 \cdot 2$ million participants. The Lan, 387(10026), 1377-1396.

Suprihatin, E., Norontoko, D. A., \& Miadi, M. (2015). Prediction of Preeclampsia by a Combination of Body Mass Index (BMI), Mean Arterial Pressure (MAP), and Roll Over Test (ROT). The Proceeding of 7th International Nursing Conference: Global Nursing Challenges in The Free Trade Era, 8-9 April 2016, Surabaya.

Syahriana. (2018). Analisis Indeks Masa Tubuh, Low Density Lipoprotein, dan High Density Lipoprotein sebagai faktor predictor hipertensi dalam kehamilan. Universitas Hasanuddin.

Walia, M., D'souza, A. S., \& Gupta, G. (2015). Comparison between Roll Over Test and Placental Localization for aerly prediction of preeclampsia. International Journal of Reproduction, Contraception, Obstetrics and Gynecology, 4(6), 1711.

World Heath Organization, United Nations Children's Fund, United Nations Population Fund, \& The World Bank. (2018). Trends in Maternal Mortality:1990 to 2008. WHO library cataloguing. 